\title{
Pleiocarpa pycnantha leaves and its triterpenes induce apoptotic cell death in Caco-2 cells in vitro

\author{
Olubunmi Adenike Omoyeni ${ }^{1 *}$, Ahmed Hussein ${ }^{1}$, Mervin Meyer ${ }^{2}$, Ivan Green ${ }^{1}$ and Emmanuel Iwuoha ${ }^{1}$
}

\begin{abstract}
Background: Recently, we reported that the crude fractions and pure triterpenes; ursolic acid (C1), 27-E and 27-Z p-coumaric esters of ursolic acid (C2, C3), together with a new triterpene 2,3-seco-taraxer-14-en-2,3-lactone [pycanocarpine (C4)] and its hydrolysed derivative - (2,3-seco-taraxen-4-hydroxy-14-en-2-oic acid) [pycanocarpene (C5)] from Pleiocarpa pycnantha leaves inhibit cell proliferation. However, there has not been any specific report on the use of Pleiocarpa pycnantha leaves and its constituents to kill colorectal adenocarcinoma cancer CaCo-2 cells. We performed in vitro study to evaluate the cytotoxic properties of the ethanolic extract of $P$. pycnantha $\mathrm{P}$, compounds C2 and C3. A preliminary study of the potential mechanisms were also undertaken.
\end{abstract}

Methods: Cell viability was measured by WST-1 assay. The Apoptosis level was evaluated by staining with APOPercentage ${ }^{\mathrm{TM}}$ dye and the induction of caspases $3 / 7$ and 9 using Caspase-Glo ${ }^{\oplus}$ assays.

Results: The exposure of an ethanolic extract from the leaves of $P$. pycnantha $(0.1-1000 \mu \mathrm{g} / \mathrm{ml})$ and the isolated compounds C2 and C3 $(6,25-100 \mu \mathrm{g} / \mathrm{ml})$ to human colorectal cancer cells reduced the cell viability with an $\mid C_{50}>100$, $40.9,36.3 \mathrm{\mu g} / \mathrm{ml}$ for P, C2 and C3 respectively, after $24 \mathrm{~h}$ of incubation. The APOPercentage ${ }^{\mathrm{TM}}$ assay also showed a considerable increase in the percentage of apoptotic cells after $24 \mathrm{~h}$; (25-38 \% for P, 5-23\% for C2 and 6-47 \% for C3). Caspase 3 was also activated which is a hallmark of apoptosis.

Conclusion: These findings suggest that the P. pycnantha and the isolated compounds induce cell apoptosis in human colorectal adenocarcinoma cells. A further study with other cell lines is also recommended.

Keywords: Apoptosis, colon cancer, Triterpenes, Pleiocarpa pycnantha, Caspases, 27- p-Z-coumaroloxy ursolic acid, 27- p-E-coumaroloxy ursolic acid

\section{Background}

Cancer is a major public health burden to both the developed and the developing nation.

The global distribution of cancer and the type of cancer that predominates continues to change, especially in economically developing countries. The low- and middle- income countries accounted for about $(51 \%)$ of all cancers worldwide in 1975 with this proportion increasing to $55 \%$ in 2007 and is projected to reach $61 \%$ by 2050 [1]. Cancers of the lung, breast, colon/rectum and prostate are no longer largely restricted to the Western industrialized countries but are among the most common cancers worldwide [2].

\footnotetext{
* Correspondence: nikxyglo@yahoo.com

${ }^{1}$ Department of Chemistry, University of the Western Cape, Bellville, South Africa

Full list of author information is available at the end of the article
}

Neoplasms are the main cause of death worldwide. Each year tumors are diagnosed in about 11 million people, ending with death in 7.6 million; the number forecasted for 2030 is in the region of 13.1 million [3].

Colorectal cancer is the third most common cancer and the third leading cause of cancer death in men and women in the United States. The American Cancer Society estimates that 136,830 people will be diagnosed with colorectal cancer and 50,310 people would have died from the disease in $2014[4,5]$. The major treatment regimen for cancer are chemotherapy and radiotherapy, which unfortunately have often proved to be toxic to other living cells in the body. Therefore, numerous studies have focused on the application of natural products to prevent and to treat cancer [6].

Natural products have also served as important chemical prototypes for the discovery of new molecules, and
C Biomed Central

(c) 2015 Omoyeni et al. This is an Open Access article distributed under the terms of the Creative Commons Attribution License (http://creativecommons.org/licenses/by/4.0), which permits unrestricted use, distribution, and reproduction in any medium, provided the original work is properly credited. The Creative Commons Public Domain Dedication waiver (http:// creativecommons.org/publicdomain/zero/1.0/) applies to the data made available in this article, unless otherwise stated. 
continue to be the most promising source of drug leads, especially in the anticancer field [7]. Among bioactive compounds, there is an important group known as the triterpenes and these have demonstrated cytotoxic properties against tumor cells on the one hand while on the other hand display low cytotoxicity towards normal cells [8].

More than 20,000 triterpenes has been isolated and identified from nature, which belong to different chemical groups such as squalene, lanostane, dammarane, lupane, oleanane, ursane, hopane, or triterpenoid sapogenins as for example, cycloartane, friedelane, filicane and cucurbitane triterpenoids [9]. Several biological activities have been reported for triterpenes, which includes; anti-cancer, anti-obesity, anti-diabetic, antiinflammatory, anti-oxidative, anti-viral, anti-bacterial, and anti-fungal properties [10-20].

Apoptosis is a controlled process of programmed cell death and plays an important role in many normal functions ranging from fetal development to adult tissue homeostasis [21]. Tumors are characterized by uncontrolled proliferation and reduced apoptosis. The activation of apoptotic pathways is a key mechanism by which cytotoxic drugs kill cancer cells. Compounds that block or suppress the growth of tumor cells by inducing apoptosis are considered to have potential as anti-tumoral agents [22].

We have reported on the cytotoxicity of $P$. pycnantha leaves and its triterpenoid contents on HeLa, HT-29, MCF-7 and KMST-6 [23]. We also discovered that the literature is very scarce on the anticancer activity of $27-E$ p-coumaroloxy ursolic acid (C2) and 27- $Z p$-coumaroloxy ursolic acid (C3), and hence the need for this research. To the best of our knowledge, this is the first report of $P$. pycnantha leaves and its constituents on the cytotoxicity, apoptosis and the molecular mechanisms on colorectal adenocarcinoma (Caco-2 cells).

\section{Methods}

\section{Plant collection and identification}

Pleiocapa pycnantha (K. Schum.) Stapf leaves were collected at Ikere Ekiti, Ekiti State, South-West, Nigeria in December, 2010. The botanical identification was done by Femi Omotayo of the Herbarium section of Plant Science Department of Ekiti State University, Ado-Ekiti, Nigeria, where a voucher specimen e-Herbarium UHAA 45 was deposited.

\section{Extraction and isolation}

The ethanolic extract of Pleiocarpa pycnantha leaves (P) and compounds $\mathrm{C} 2$ (27-E p-coumaroloxyursolic acid) and C3 (27-Z p-coumaroloxyursolic acid) were obtained as previously described by Omoyeni et al., [23]. Briefly, the ground air-dried leaves of Pleiocarpa pycnantha $(\sim 1.0 \mathrm{~kg})$ was extracted by cold maceration using $95 \%$ ethanol for 3 days to obtain $81.0 \mathrm{~g}$. About $(62.0 \mathrm{~g})$ of the ethanol extract was adsorbed in silica gel and ran on silica gel open column using hexane/EtOAc of varying polarities to obtain 13 fractions labelled as P1-P13. Fractions P4, P7, $\mathrm{P} 8, \mathrm{P} 9$ and $\mathrm{P} 12$ displayed cytotoxic activities, varying from strong to moderate activities.

Fraction P12 (5.2 g) was further chromatographed on silica gel column using EtOAc/hexane (50:50-100:0) to afford sub-fraction A-H. The sub-fraction P12E (140 mg) was further purified on sephadex LH-20 column using $\mathrm{DCM} / \mathrm{MeOH}(95: 5)$ and HPLC $(\mathrm{MeOH} / \mathrm{H} 2 \mathrm{O}, 80: 20)$ to afford compound C2 (5.5 mg) and C3 (7.3 mg); their chemical structures are illustrated in Fig. 1.

\section{Chemicals and reagents}

Ethanol, dimethyl sulfoxide (DMSO) penicillin-streptomycin and potassium iodide (PI) were purchased from Sigma-Aldrich (St. Louis, MO, USA). DMEM was purchased from Gibco, USA, Fetal bovine serum from Roche, US and trypsin from Invitrogen, Grand Island, New York.

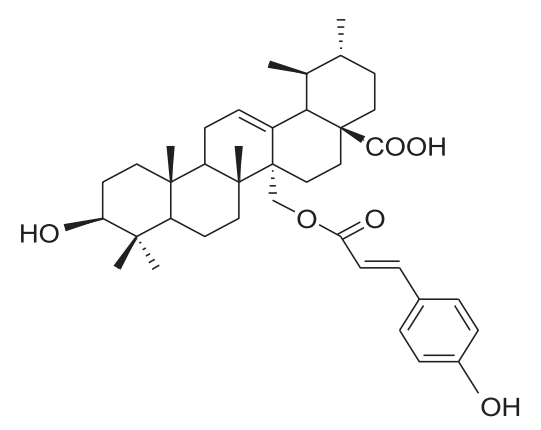

27-p- $E$-coumaroloxyursolic acid (C2)

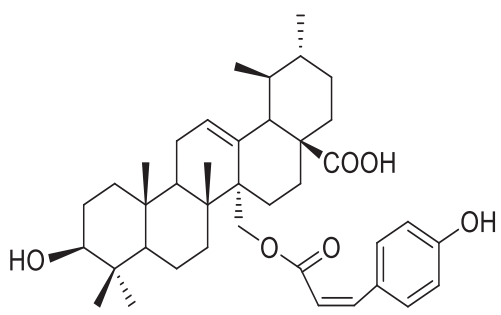

27-p-Z-coumaroloxyursolic acid (C3)

Fig. 1 Chemical structure of compounds C2 and C3 [12] 
Tissue culture flasks, 12 and 96-well plates were obtained from TPP (Trasadingan, Switzerland). APOPercentage ${ }^{\text {Tn }}$ dye was obtained from Biocolor, UK. Caspase 9 and 3/7 were purchased from Promega, Madison, WI, USA. The WST-1 tetrazolium dye was obtained from (Roche Diagnostics $\mathrm{GmbH}$, Mannheim, Germany).

\section{Cell culture}

The Caco-2 (human colorectal adenocarcinoma) cell line was obtained from American Type Culture Collection (ATCC; Manassas, VA, USA). The cells were maintained in a $37{ }^{\circ} \mathrm{C}$ humidified incubator with $5 \% \mathrm{CO}_{2}$ saturation. The cells were further maintained in Dulbecco's Modified Eagle's medium containing $10 \%$ fetal bovine serum, and $1 \%$ penicillin-streptomycin. All cell culture reagents were obtained from Invitrogen Ltd. (Grand Island, New York). Cells were either plated in 6-well cell culture plates at a cell density of $2.5 \times 10^{5}$ cells per well or in 24 well cell culture plates at a cell density of $1 \times$ $10^{5}$ cells per well or in a 96-well cell culture plates at a cell density of $2 \times 10^{4}$ cells per well.

\section{Cell viability assay}

Cells were seeded in 96-well culture plates at a density of $2 \times 10^{4}$ cells/well and incubated at $37^{\circ} \mathrm{C}$ for $24 \mathrm{~h}$. The next day, cells were exposed to several concentrations of P $(0.1-1000 \mu \mathrm{g} / \mathrm{ml}), \mathrm{C} 2(6,25-100 \mu \mathrm{g} / \mathrm{ml})$, and C3 $(6,25-100 \mu \mathrm{g} / \mathrm{ml})$. These were further incubated for $24 \mathrm{~h}$, after which the cell viability was measured using the WST- 1 assay. The WST- 1 reagent $(10 \mu l)$ was added to each well and incubated for $4 \mathrm{~h}$ at $37{ }^{\circ} \mathrm{C}$ under $5 \%$ $\mathrm{CO}_{2}$ in a humidified incubator. The plates were shaken for $1 \mathrm{~min}$ on a shaker and the absorbance of the samples measured at $450 \mathrm{~nm}$ (reference wavelength was $750 \mathrm{~nm}$ ) using a Promega Micro-plate (Madison, WI, USA). Cytotoxicity was expressed as a percentage of the absorbance measured in control untreated cells. $\mathrm{IC}_{50}$ values were calculated using Prism Graph pad software. Triplicates experiment and the results expressed as mean \pm SEM [23].

\section{APOPercentage $^{\mathrm{TM}}$ assay}

The induction of apoptosis was assessed using the APOPercentage assay (Biocolor Ltd., UK). The cells were plated in 24 well cell culture plates at a density of $1 \times$ $10^{5}$ cells per well. After $24 \mathrm{~h}$ the spent medium was replaced with fresh medium containing $10-100 \mu \mathrm{g} / \mathrm{ml}$ of the extract $\mathrm{P}$ and $12.5-50 \mu \mathrm{g} / \mathrm{ml}$ of the isolated compounds ( $\mathrm{C} 2$ and $\mathrm{C} 3)$. The extract and compounds were dissolved in DMSO prior to adding it to culture medium. The final concentration of DMSO in the treated wells was lower than $1 \%(\mathrm{v} / \mathrm{v})$. As a negative control, cells were left untreated, while cells treated with $50 \mu \mathrm{M}$ cisplatin (a known inducer of apoptosis) served as a positive control. All treatments were done in triplicate. The cells were treated for $24 \mathrm{~h}$, after which the cells were harvested by gentle trypsinization. The cells were stained with the APOPercentage $\mathrm{e}^{\mathrm{m}}$ dye and analysed by flow cytometry on a Becton Dickinson FACScan instrument (BD Pharmingen ${ }^{\mathrm{Tm}}$, USA) as described by Meyer et al., [24].

\section{Caspase $3 / 7$ and 9 assay}

Caspases 9 and $3 / 7$ activity was measured using the Caspase-Glo 9 and Caspase-Glo ${ }^{\circ}$ 3/7 assays (Promega Corp., USA) according to the method described by Chakravarti et al., [25] with slight modifications. Caco-2 cells were plated in 96-well cell culture plates and treated for 6 , 12 and 24 h with $10-100 \mu \mathrm{g} / \mathrm{ml}$ of extract $\mathrm{P}$ and $12.5-$ $25 \mu \mathrm{g} / \mathrm{ml}$ of C2, C3 and evaluated for caspases 9 and 3/ 7 activities. After treatments, the cells were lysed and the cleavage of the substrate by caspases was measured by the generated luminescent signal with a 96 multi-well Glomax luminometer (Promega Corporation, USA).

\section{Statistical analysis}

Data were represented as mean \pm SEM of at least three independent experiments. Data were analyzed using Prism Graph Pad software (San Diego, USA). Statistical test two-way ANOVA and Bonferroni post hoc test were conducted for pairwise comparisons. $P$ value less than 0.05 was considered statistically significant.

\section{Results}

Extract $\mathrm{P}$, compounds $\mathrm{C} 2$ and $\mathrm{C} 3$ decreased cell viability P. pycnantha extract (P), isolated compounds (C2 and $\mathrm{C} 3$ ) decreased cell viability of Caco- 2 cells. We examined the effect of $P$. pycnantha ethanolic extract and compounds $\mathrm{C} 2$ and C3 in cell viability using WST- 1 assay. Caco- 2 cells were treated with various concentrations of the extract and compounds $\mathrm{C} 2$ and $\mathrm{C} 3$, their viability was determined by the uptake of the formazan dye and expressed as percent of untreated control cells. The extract and the compounds induced a dose-dependent increase in viable formazan accumulating cells after the treatment (Fig. 2a and b). The $50 \%$ growth inhibition concentration $\mathrm{IC}_{50}$ obtained after $24 \mathrm{~h}$ of incubation were $>100,40.9,36.3 \mu \mathrm{g} / \mathrm{ml}$ for P, C2 and C3 respectively.

\section{P. pycnantha extract ( $\mathrm{P})$, isolated compounds (C2 and C3) induced apoptosis of Caco-2 cells}

The effect of $P$. pycnantha extract $\mathrm{P}$ and compounds $\mathrm{C} 2$ and $\mathrm{C} 3$ on Caco-2 cell growth was assessed using the APOPercentage ${ }^{\mathrm{Tm}}$ dye which detect apoptosis at the stage of phosphatidylserine externalization and its specific for the quantitation of apoptosis. Caco-2 cells were treated for $24 \mathrm{~h}$ with different concentrations of $\mathrm{P}, \mathrm{C} 2$ and $\mathrm{C} 3$ and stained with APOPercentage ${ }^{\mathrm{Tw}}$ dye and analysed by flow 


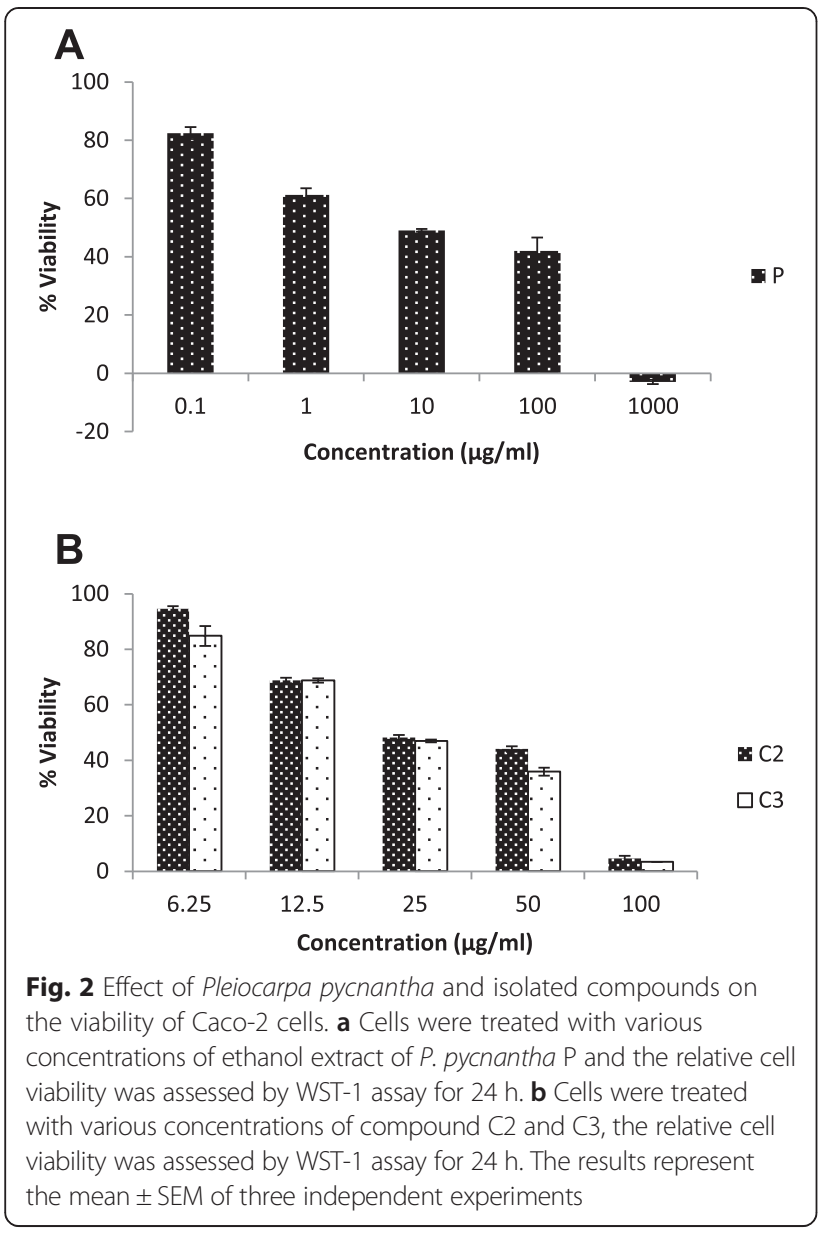

cytometry. The extract $\mathrm{P}$ and the tested compounds induced significant levels of apoptosis between (25-38 \% for P, 5-23\% for C2 and 6-47\%) in Caco-2 cells (Fig.3a and b). The extract and compounds induce apoptosis in a dose-dependent manner. The cytotoxicity caused by the extract P and compounds $\mathrm{C} 2$ and $\mathrm{C} 3$ may be due to in part to anti-proliferative and pro-apoptotic effects.

\section{P. pycnantha extract (P), isolated compounds (C2 and C3) induce caspase $3 / 7$ and 9 activity in Caco-2 cells}

The activation of caspases, which are mediators of apoptosis was analysed upon exposure of Caco-2 cells to the P. pycnantha ethanol extract and the compounds $\mathrm{C} 2$ and C3. The expression of caspase $3 / 7$ and 9 activity was measured in cells exposed to several concentrations of the extract $(10-100 \mu \mathrm{g} / \mathrm{ml})$ for $6-24 \mathrm{~h}$ or incubated with $\mathrm{C} 2$ and $\mathrm{C} 3(12.5-25 \mu \mathrm{g} / \mathrm{ml})$ for $6-24 \mathrm{~h}$. The levels of caspase activation in Caco-2 cells were compared with untreated control cells arbitrarily set to 1.0, the results showed that the extract $\mathrm{P}$ significantly increase caspase $3 / 7$ activation at different concentrations and time. At $\mathrm{P} 10 \mu \mathrm{g} / \mathrm{ml}$, the caspase $3 / 7$ activity reached a maximum (1.62 fold increase at $24 \mathrm{~h}$ (Fig.4a). A similar occurrence

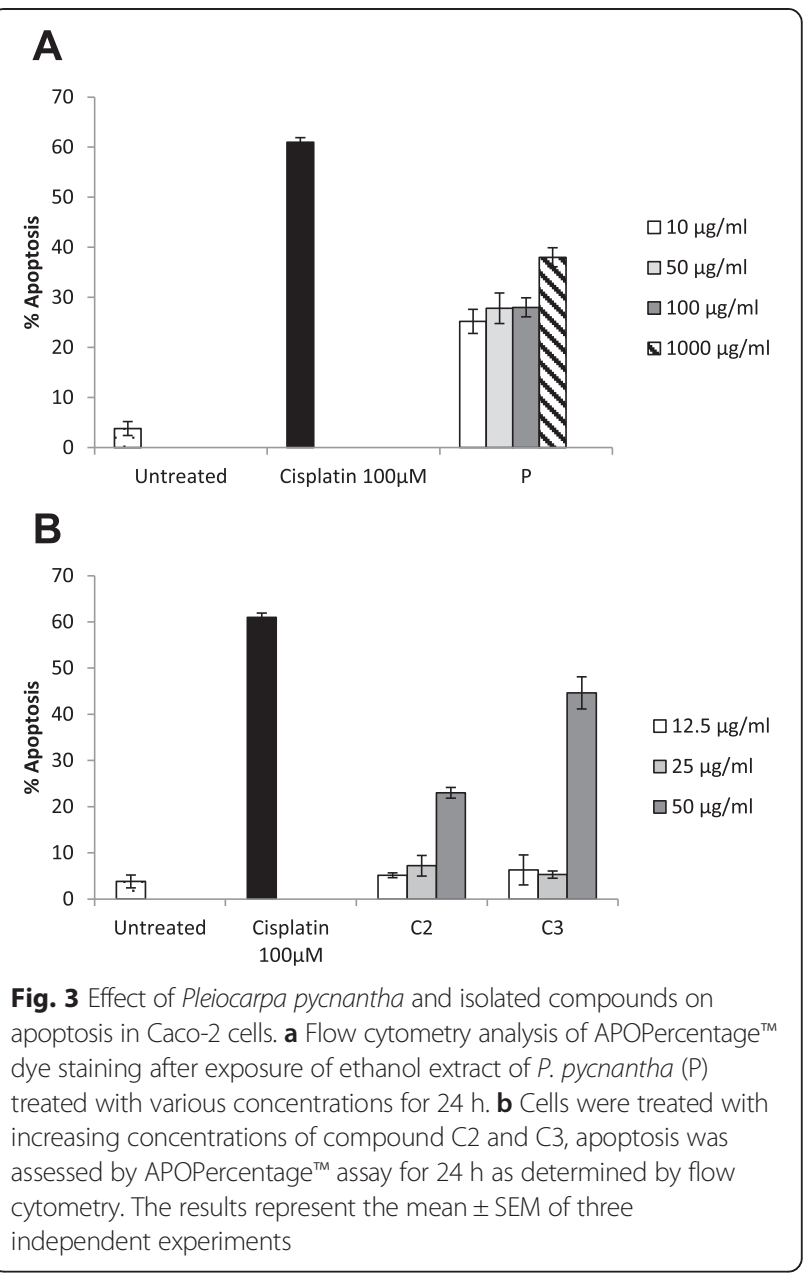

was observed at P100 $\mu \mathrm{g} / \mathrm{ml}$ (1.35 fold increase), while at P50 $\mu \mathrm{g} / \mathrm{ml}$, the maximum caspase activity was recorded at $12 \mathrm{~h}$ with approximate fold increase being 1.49 (Fig.4a). Furthermore, compound $\mathrm{C} 2$ at $12.5 \mu \mathrm{g} / \mathrm{ml}$ showed a significant caspase $3 / 7 \approx 2.0$ fold increase activity as early as $6 \mathrm{~h}$ while $\mathrm{C} 3$ at the same dose had about 1.1 fold increase (Fig.4b and c). At $12 \mathrm{~h}$, compound C3 $(12.5 \mu \mathrm{g} / \mathrm{ml})$ also showed a marked increase caspase activity (1.76 fold increase) as compared with the control, $\mathrm{C} 2$ at a similar dose showed only 1.2 fold increase when compared with the control. A similar trend was also observed at $24 \mathrm{~h}$ of treatment. Compounds $\mathrm{C} 2$ and C3 did not show any significant effect on caspase activation at a higher dose of $25 \mu \mathrm{g} / \mathrm{ml}$ at $6-24 \mathrm{~h}$ of treatment (Fig.4b and c). The result of caspase 9 activity of P, C2 and C3 on Caco-2 cells are shown in Fig.5a-c. The result further showed that at concentrations $10-100 \mu \mathrm{g} / \mathrm{ml}, \mathrm{P}$ significantly activated caspase 9 at different time points as compared with the untreated control except at $6 \mathrm{~h}$ for P10 $\mu \mathrm{g} / \mathrm{ml} \mathrm{(Fig.} \mathrm{5a).} \mathrm{At} \mathrm{concentrations,} \mathrm{10,} \mathrm{50,} \mathrm{and}$ $100 \mu \mathrm{g} / \mathrm{ml}$, the maximum caspase 9 activity fold increase obtained were $1.69,1.79$ and 1.45 at $24 \mathrm{~h}$ and $12 \mathrm{~h}$ 

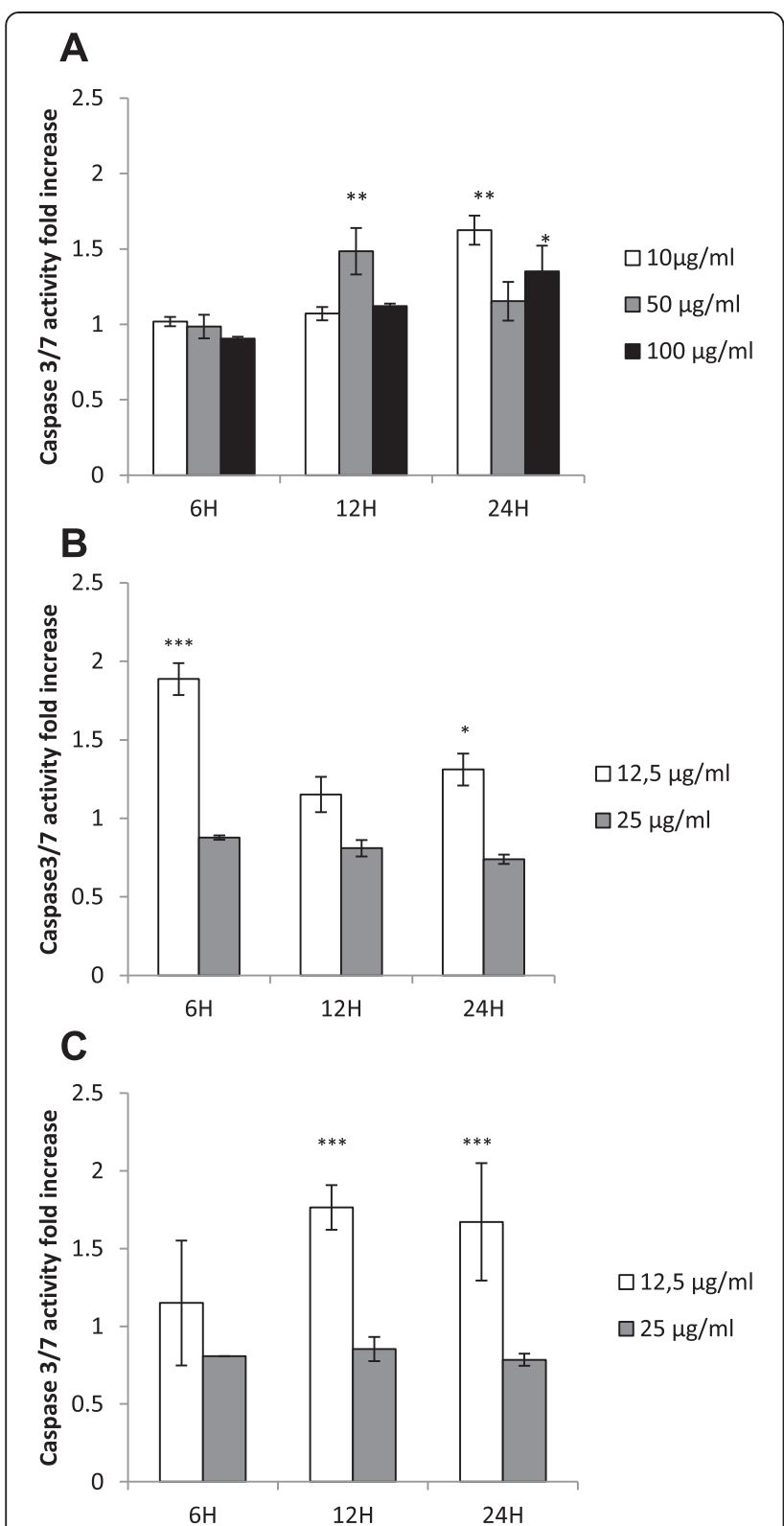

Fig. 4 Pleiocarpa pycnantha and isolated compounds apoptosis is mediated by caspase $3 / 7$ activation. a Treatment of cells with various concentration of extract $P$ for 6-24 h (P) treated with various concentrations for $24 \mathrm{~h}$. b Cells were treated with increasing concentrations of compound C2 for 6-24 h. c Measurement of caspase $3 / 7$ activity when cells were treated with different concentrations of compound C3 for 6-24 h. Data are presented as mean \pm SEM, ${ }^{* *} \mathrm{P}<0.001,{ }^{* *} \mathrm{P}<0.01$ and ${ }^{*} \mathrm{P}<0.05$ compared with control

respectively. At $25 \mu \mathrm{g} / \mathrm{ml}, \mathrm{C} 2$ showed a significant increased caspase 9 activity within 6-24 h of treatment with 1.34-1.41 fold increase (Fig. 5b). Similarly, compound $\mathrm{C} 3$ at $25 \mu \mathrm{g} / \mathrm{ml}$ showed an increased caspase 9 activity when compared with the untreated control within 6-24 h from 1.05-1.27 (Fig. 5c). Only a slight increase
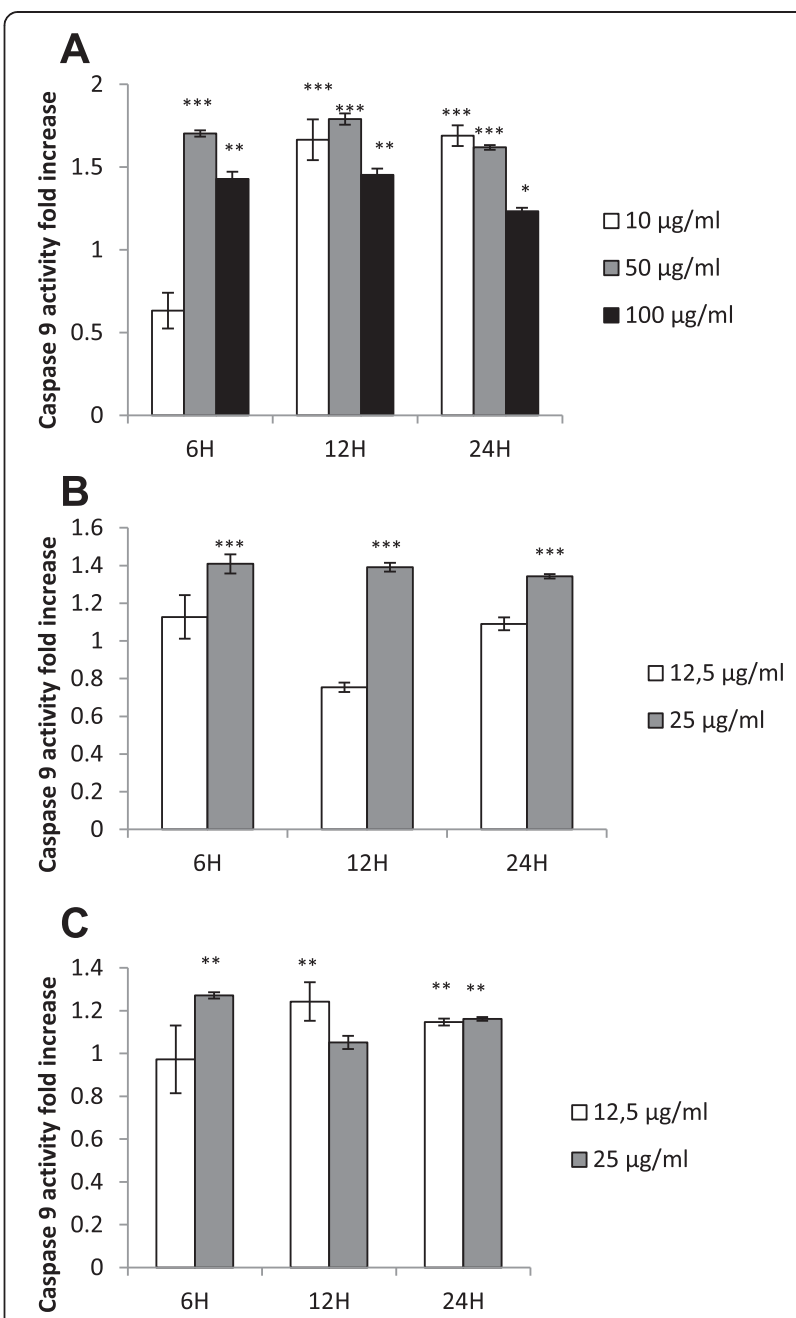

Fig. 5 Measurement of caspase 9 activity by Pleiocarpa pycnantha and isolated compounds. a Treatment of cells with various concentration of extract $P$ for $6-24$ h. b Cells were treated with increasing concentrations of compound C2 for 6-24 h. c Measurement of caspase 9 activity when cells were treated with different concentrations of compound C3 for 6-24 h. Data are presented as mean \pm SEM, ${ }^{* * *} \mathrm{P}<0.001,{ }^{* *} \mathrm{P}<0.01$ and ${ }^{*} \mathrm{P}<0.05$ compared with control

was observed at the concentration $12.5 \mu \mathrm{g} / \mathrm{ml}$ for both $\mathrm{C} 2$ and $\mathrm{C} 3$ at $6-24 \mathrm{~h}$.

\section{Discussion}

During the past decades, much of effort has been undertaken towards the search for compounds or herbs that kill tumors through induction of apoptosis $[26,27]$. Triterpenoids have been reported to exert various pharmacological effects to control a plethora of diseases including cancer $[28,29]$. Our previous paper described the cytotoxic properties of these compounds and a crude extract on a panel of cell lines [23]. However their antitumor capacity against colorectal cancer has not been studied. 
The present study describes an evaluation of the potential anticancer effects of the crude ethanolic extract $\mathrm{P}$ and two pure isolated compounds $\mathrm{C} 2$ and $\mathrm{C} 3$ from $P$. pycnantha.

Our data illustrates that the extract $\mathrm{P}$ and the compounds $\mathrm{C} 2$ and $\mathrm{C} 3$ demonstrated anti- proliferative and pro-apoptotic effects on Caco-2 colorectal adenocarcinoma cell line in a dose -dependent manner. Using WST-1 assay, we have demonstrated that both extract and the compounds supressed Caco-2 cell viability with C3 displaying a more pronounced activity. The three agents also induce morphological changes, such as cell shrinkage and detachment which were observed under microscope (data not shown).

The anti-proliferative capacity of uvaol, erythrodiol, oleanolic acid and maslinic acid have been reported [30]. It has also been reported that some anticancer agents cause growth inhibition through interfering with the process of the cell cycle [31] while others cause cell death by apoptosis [32]. We further tested the extract P and compounds $\mathrm{C} 2$ and $\mathrm{C} 3$ for apoptosis using the APOPercentage ${ }^{\mathrm{TM}}$ assay quantified by flow cytometry. The result showed that the percentage of apoptotic cells increased for P, C2 and C3 from 25-38, 5-23 and 6$47 \%$ respectively after $24 \mathrm{~h}$ treatments. The execution of apoptosis seems to be uniformly mediated through consecutive activation of the members of a caspase family [33].

We further examined whether the apoptotic effect could be linked to induction of caspase activation. Our data demonstrated that as early as $12 \mathrm{~h}, \mathrm{P}$ at a concentration of $50 \mu \mathrm{g} / \mathrm{ml}$ showed a significant rise in caspase $3 / 7$ activity while $\mathrm{P}$ at a concentration of $10 \mu \mathrm{g} / \mathrm{ml}$, and $\mathrm{P}$ at a high concentration of $100 \mu \mathrm{g} / \mathrm{ml}$ only increased caspase activation after $24 \mathrm{~h}$ of treatment. Further to this, compounds $\mathrm{C} 2$ at $12.5 \mu \mathrm{g} / \mathrm{ml}$ peaked after $6 \mathrm{~h}$ with about 1.89 fold increase while the maximum caspase activity was recorded for $\mathrm{C} 3$ at $12.5 \mu \mathrm{g} / \mathrm{ml}$ after $12 \mathrm{~h}$. Since activation of caspase 3 is a hall mark of apoptosis, this is an indication that apoptosis has taken place in the cells. The result obtained from the induction of caspase 9 activity showed that all the concentration of the crude extract $\mathrm{P}$ activated caspase 9 except at $6 \mathrm{~h}$ for $\mathrm{P}$ at $10 \mu \mathrm{g} / \mathrm{ml}$. There was also a slight activation of caspase 9 at a higher dose of $25 \mu \mathrm{g} / \mathrm{ml}$ for C2 and C3.

\section{Conclusion}

The crude extract $\mathrm{P}$ and compounds $\mathrm{C} 2$ and $\mathrm{C} 3$ showed a significant anti-proliferative effect on Caco- 2 cells. To the best of our knowledge, this is the first report on the induction of apoptosis in colorectal adenocarcinoma cells for the extract of $P$. pycnantha and two of its pure compounds. The apoptotic pathway is also characterized by the activation of caspases cascade (vis caspase 9) which culminated in caspase- 3 activation. Triterpenoids such as ursolic acid, corosolic acid and maslinic acid have been reported to induce apoptosis by a similar mechanism [28, 29, 34]. However, further studies need to be done regarding alternative mechanisms viz., caspase 8, ROS and cell cycle in order to obtain further clarity about the actual mechanism. Nevertheless, we hope our findings are able to contribute to the development of the crude extract and isolated compounds into viable anticancer agents.

\section{Abbreviations}

WST-1: (4-[3-(4-lodophenyl)-2-(4-nitrophenyl)-2H-5-tetrazolio]-1,3-benzene disulfonate); ANOVA: Analysis of variance; DMSO: Dimethyl sulfoxide; PBS: Phosphate buffered saline.

\section{Competing interests}

The authors declare that they have no competing interests.

\section{Authors' contributions}

$\mathrm{OAO}$ designed the study, performed the experiments and drafted the manuscripts. MM and AH directed the study. AH, MM, IR and El corrected the manuscript. All authors read and approved the final manuscript.

\section{Acknowledgements}

The authors are grateful to Ronnie Dreyer (UCT) for assistance with flow cytometry, Nicole Sibuye and Badmus Jelili for some laboratory assistance at Biotechnology and Medical Bioscience departments at UWC.

\section{Author details}

'Department of Chemistry, University of the Western Cape, Bellville, South Africa. ${ }^{2}$ Department of Biotechnology, Apoptosis Research Unit, University of the Western Cape, Bellville, South Africa.

Received: 22 December 2014 Accepted: 6 July 2015

Published online: 14 July 2015

\section{References}

1. Bray F, Ren JS, Masuyer E, Ferlay J. Global estimates of cancer prevalence for 27 sites in the adult population in 2008. Int J Cancer. 2013;132:1133-45.

2. Thun MJ, DeLancey JO, Center MM, Jemal A, Ward EM. The global burden of cancer: priorities for prevention. Carcinogenesis. 2010;31:100-10.

3. World Health Organization :Available online: http://www.who.int/ mediacentre/factsheets/fs297/en/(accessed on 26 October 2014).

4. Siegel R, DeSantis C, Jemal A. Colorectal cancer statistics. CA Cancer J Clin. 2014;64:104-17.

5. American Cancer Society (ACS). Colorectal Cancer Facts \& Figures 2014-2016. Atlanta: American Cancer Society; 2014. p. 1-10.

6. Chudzik M, Korzonek-Szlacheta I, Król W. Triterpenes as potentially cytotoxic compounds. Molecules. 2015;20:1610-25.

7. Li Y, Kim S. "Triterpenoids as Anticancer Drugs from Marine Sponges." Handbook of Anticancer Drugs from Marine Origin. Switzerland: Springer International Publishing; 2015. pp 15-27.

8. Zuco V, Supino R, Righetti SC, Cleris L, Marchesi E, Gambacorti-Passerini C, et al. Selective cytotoxicity of betulinic acid on tumor cell lines, but not on normal cells. Cancer Lett. 2002;175:17-25.

9. Connolly JD, Hill RA. Triterpenoids. Nat Prod Rep. 2001;18:560-78.

10. Nho KJ, Chun JM, Kim HK. Corosolic acid induces apoptotic cell death in human lung adenocarcinoma A549 cells in vitro. Food Chem Toxicol. 2013;56:8-17.

11. Bishayee A, Ahmed S, Brankov N, Perloff M. Triterpenoids as potential agents for the chemoprevention and therapy of breast cancer. Front Biosci (Landmark Ed). 2011;16:980-96.

12. Liu J. Pharmacology of oleanolic acid and ursolic acid. J Ethnopharmacol. 1995;49:57-68

13. Banno N, Akihisa T, Tokuda H, Yasukawa K, Higashihara H, Ukiya M, et al. Triterpene acids from the leaves of Perilla frutescens and their anti-inflammatory and antitumor-promoting effects. Biosci Biotechnol Biochem. 2004;68:85-90. 
14. Liaw CC, Chen YC, Huang GJ, Tsai YC, Chien SC, Wu JH, et al. Anti-inflammatory lanostanoids and lactone derivatives from Antrodia camphorata. J Nat Prod. 2013;76:489-94.

15. Fukushima M, Matsuyama F, Ueda N, Egawa K, Takemoto J, Kajimoto Y, et al. Effect of corosolic acid on postchallenge plasma glucose levels. Diabetes Res Clin Pract. 2006;73:174-7.

16. Zong W, Zhao G. Corosolic acid isolation from the leaves of Eriobotrta japonica showing the effects on carbohydrate metabolism and differentiation of 3 T3-L1 adipocytes. Asia Pac J Clin Nutr. 2007;1:346-52.

17. De Silva ML, David JP, Silva LC, Santos RA, David JM, Lima LS, et al. Bioactive oleanane, lupane and ursane triterpene acid derivatives. Molecules. 2012;17:12197-205.

18. Galaiko NV, Tolmacheva IA, Grishko W, Volkova LV, Prevozchikova EN, Pestereva SA. Antiviral activity of 2,3-secotriterpenic hydrazones of lupane and 19beta,28-epoxy-18alpha-oleanane type. Bioorganicheskaya Khimiya. 2010;36:556-62.

19. Ahmed $Y$, Sohrab MH, Al-Reza SM, Tareq FS, Hasan CM, Sattar MA Antimicrobial and cytotoxic constituents from leaves of Sapium baccatum. Food Chem Toxicol. 2010;48:549-52.

20. Mokoka TA, McGaw LJ, Mdee LK, Bagla VP, Iwalewa EO, Eloff JN. Antimicrobial activity and cytotoxicity of triterpenes isolated from leaves of Maytenus undata (Celastraceae). BMC Complement Altern Med. 2013;13:111.

21. Reed JC. Apoptosis-regulating proteins as targets for drug discovery. Trends Mol Med. 2001;7:314-9.

22. Frankfurt OS, Krishan A. Apoptosis-based drug screening and detection of selective toxicity to cancer cells. Anticancer Drugs. 2003;14:555-61.

23. Omoyeni O, Meyer M, Iwuoha E, Green I, Hussein A. An Unusual 2,3-Secotaraxerene and Other Cytotoxic Triterpenoids from Pleiocarpa pycnantha (Apocynaceae) Leaves Collected from Nigeria. Molecules. 2014;19:3389-400.

24. Meyer M, Essack M, Kanyanda S, Rees J. A low-cost flow cytometric assay for the detection and quantification of apoptosis using an anionic halogenated fluorescein dye. Biotechniques. 2008:45:317-20.

25. Chakravarti B, Maurya R, Siddiqui JA, Bid HK, Rajendran SM, Yadav PP, et al. In vitro anti-breast cancer activity of ethanolic extract of Wrightia tormentosa: role of pro-apoptotic effects of oleanolic acid and ursolic acid. J Ethnopharmacol. 2012;142:72-9.

26. Shafi G, Munshi A, Hasan TN, Alshatwi AA, Jyothy A, Lei DK. Induction of apoptosis in HeLa cells bychloroform fraction of seed extracts of Nigella sativa. Cancer Cell Int. 2009;9:29.

27. Einbond LS, Wen-Cai Y, He K, Wu HA, Cruz E, Roller M, et al. Growth inhibitory activity of extracts and compounds from Cimicifuga species on human breast cancer cells. Phytomedicine. 2008;15:504-11.

28. Xu Y, Ge R, Du J, Xin H, Yi T, Sheng J, et al. Corosolic acid induces apoptosis through mitochondrial pathway and caspases activation in human cervix adenocarcinoma HeLa cells. Cancer Lett. 2009;284:229-37.

29. Reyes-Zurita FJ, Rufino-Palomares EE, Lupianez JA, Cascante M. Maslinic acid, a natural triterpene from Olea europaea L., induces apoptosis in HT-29 human colon-cancer cells via the mitochondrial apoptotic pathway. Cancer Lett. 2009;273:44-5.

30. Allouche Y, Warleta F, Campos M, Sánchez-Quesada C, Uceda M, Beltrán G, et al. Antioxidant, antiproliferative, and pro-apototic capacities of pentacyclic triterpenes found in the skin of olives on MCF-7 human breast cancer cells and their effects on DNA damage. J Agric Food Chem. 2011;59:121-30

31. Schwartz GK, Shah MA. Targeting the cell cycle: a new approach to cancer theraphy. J Clin Oncol. 2005;23:9408-21.

32. Thompson CB. Apoptosis in the pathogenesis and treatment of disease. Science. 1995;267:1456-62.

33. Philchenkov A. Caspases:potential targets for regulating cell death. J Cell Mol Med. 2008;8:432-44.

34. Harmand PO, Duval R, Delage C, Simon A. Ursolic acid induces apoptosis through mitochondrial intrinsic pathway and caspase-3 activationin M4Beu melanoma cells. Int J Cancer. 2005;114:1-11.

\section{Submit your next manuscript to BioMed Central and take full advantage of:}

- Convenient online submission

- Thorough peer review

- No space constraints or color figure charges

- Immediate publication on acceptance

- Inclusion in PubMed, CAS, Scopus and Google Scholar

- Research which is freely available for redistribution

Submit your manuscript at www.biomedcentral.com/submit 